\title{
T300A GENETIC POLYMORPHISM: a susceptibility factor for Crohn's disease?
}

\author{
Bruno Lorenzo SCOLARO', Emily dos SANTOS ${ }^{1}$, Leslie Ecker FERREIRA ${ }^{1}$, \\ Paulo Henrique Condeixa de FRANÇA ${ }^{1}$, Harry KLEINUBING Jr. ${ }^{1}$, \\ Paulo Gustavo KOTZE² and Mauro de Souza Leite PINHO'
}

\begin{abstract}
Context - Crohn's disease is characterized by a chronic and debilitating inflammatory disorder of the gastrointestinal tract. Several factors may contribute to its development. From extensive studies of the human genome, the polymorphism T300A of the gene ATG16L1 (autophagy-related 16-like 1) has been related to increased risk of developing this disease. Objectives - Analyze the role of polymorphism T300A (rs2241880) in patients with Crohn's disease. Methods - 238 samples from (control group) and 106 samples from patients with Crohn's disease recruited at five Southern Brazilian reference centers were evaluated. The genotyping consisted of the amplification via Polymerase Chain Reaction of the genomic segment encompassing T300A, followed by Restriction Fragment Length Polymorphism analysis. The amplicons and fragments were separated by agarose gel electrophoresis and confirmed under ultraviolet light. Results - The genotype AG was more prevalent among patients and controls ( $50 \% \mathrm{vs} 44.8 \%$ ), followed by genotypes AA $(26.4 \%$ vs $35.1 \%)$ and GG $(23.6 \%$ vs $20.1 \%)$. The frequency of the allele $\mathrm{G}$ of the polymorphism T300A was higher in the group of patients with Crohn's disease (48.6\%) than in controls (42.4\%), although not reaching statistical significance. Conclusion - It was not possible to confirm the increased susceptibility on development of Crohn's disease conferred by polymorphism T300A.
\end{abstract}

HEADINGS - Crohn's disease. Carrier proteins, genetics. Single-nucleotide polymorphism.

\section{INTRODUCTION}

Crohn's disease $(\mathrm{CD})$ is characterized by a chronic and debilitating inflammatory disorder of the gastrointestinal tract showing different clinical presentations. It may occur anywhere in the digestive tract, although most commonly involving the terminal ileum, presenting discontinuous and transmural ulcerations often associated with stenosis and fistulas ${ }^{(4,7,10)}$.

Despite its increasing incidence and prevalence, the understanding of the etiopathogenic mechanisms remains a major challenge. It is known, however, that a variety of factors contribute to its development, such as environmental influences, intestinal microbiota, aberrant immune responses and the individual genetic predisposition $^{(2,3,15,16,18)}$.

From extensive studies of the human genome (Genome-wide Association Studies; GWAS), a gene of apparent relevance to $C D$ was identified. Named as ATG16L1 (autophagy-related 16-like 1), its product plays an important role in the innate immune response and in the resistance to intracellular pathogens $\mathbf{s}^{(9,13,14)}$.
Several polymorphisms have been identified in the gene ATG16L1, highlighting the single-nucleotide polymorphism (SNP) T300A (rs2241880), which appears to confer an increased risk of developing inflammatory bowel diseases (IBD) ${ }^{(3,5,8,17,19)}$.

Considering the limited data available regarding the Brazilian population, the aim of this study was to analyze the role of the SNP T300A of the gene ATG16L1 as a possible predisposing factor for the occurrence of CD.

\section{METHODS}

\section{Patients}

Single blood samples from 106 patients with confirmed diagnosis of CD, collected between 2011 and 2012, were evaluated.

Patients were recruited in five reference centers for the treatment of the disease, namely, Inflammatory Bowel Disease Clinic of the Hospital São José, Joinville/SC ( $\mathrm{n}=40)$, Inflammatory Bowel Disease Clinic of the University of Vale do Itajaí - Univali,

Declared conflict of interest of all authors: none

Sources of Research Funding: Fundo de Apoio a Pesquisa - FAP / Univille

Research performed at: Laboratório de Biologia Molecular Universidade da Região de Joinville - UNIVILLE - Joinville Santa Catarina, Brasil.

${ }_{1}^{1}$ Universidade da Região de Joinville - UNIVILLE, Joinville, SC, Brasil; ² Departamento de Medicina da Pontifícia Universidade Católica do Paraná - PUCPR, Curitiba, PR, Brasil

Correspondence: Bruno Scolaro. Departamento de Medicina, Universidade da Região de Joinville (UNIVILLE). Rua Paulo Malschitzki, 10, Campus Universitário, Zona Industrial -89219-710 - Joinville, SC, Brasil. E-mail: brunoscolaro@gmail.com 
Itajaí/SC $(\mathrm{n}=21)$; Coloproctology Service of the University Hospital Cajurú (SeCoHUC), Pontifical Catholic University of Paraná - PUCPR, Curitiba/PR ( $=32$ ), Inflammatory Bowel Disease Clinic of the Hospital of the Federal University of Paraná - HC/UFPR, Curitiba/PR $(n=9)$ and Inflammatory Bowel Disease Clinic of the Hospital Santa Isabel, Blumenau/SC $(\mathrm{n}=4)$.

The inclusion of these patients occurred in a consecutive way, regardless of their age, gender, skin color, general health status and social stratum.

\section{Controls}

The blood samples from 238 blood donation volunteers of the Regional Blood Bank (HEMOSC) were collected in the same period of time. Donors with consanguineous kinship were excluded. The HEMOSC is located in the city of Joinville/SC, southern of Brazil, approximately $100 \mathrm{~km}$ away from the other four patients recruitment centres; thus it is not expected relevant ethnic/racial differences between patients and controls.

\section{DNA Extraction}

The peripheral blood sample of patients with $\mathrm{CD}$ was obtained by finger puncture, followed by the collection and storage on FTA Elute Micro Card ${ }^{\circledR}$ (Whatman, Kent, UK). The genomic DNA extraction was performed according to the card manufacturer's specifications. The extraction and purification procedures of the genomic DNA of the samples belonging to the control group were carried out using the Qiamp DNA Mini Kit (Qiagen, Hilden, Germany), according to the manufacturer's instructions.

\section{Genotyping of SNP T300A (rs2241880)}

The methodology employed for SNP T300A genotyping was based on the study of Csongei et al..$^{(5)}$, consisting of the partial amplification of the segment containing rs 2241880 via PCR (Polymerase Chain Reaction), followed by allelic discrimination via RFLP (Restriction Fragment Lenght Polymorphism). Each PCR reaction $(50 \mu \mathrm{L})$ received $1 \mu \mathrm{L}$ dNTP's $(10 \mathrm{mM}), 0.2 \mu \mathrm{L}$ Platinum ${ }^{\circledR}$ Taq DNA Polymerase (5 U/ $\mu \mathrm{L}$; Invitrogen, São Paulo, Brazil), $5 \mu \mathrm{L}$ reaction buffer (10x), 1.5 !!!!!! $\mu \mathrm{L}$ magnesium chloride $(50 \mathrm{mM}), 1 \mu \mathrm{L}$ of each primer (10 pmol/reaction; Forward - CTCTGTCACCATATCAAGCGTGG, Reverse - TCTAGAAGGACAGGCTATCAACAGATG; Eurofins MWG Operon, Huntsville, USA) and $2 \mu \mathrm{L}$ of DNA (50 to $500 \mathrm{ng}$ ). The amplifications were conducted under the following reaction conditions: initial denaturation at $94^{\circ} \mathrm{C}$ for 3 minutes followed by 35 cycles of denaturation at $94^{\circ} \mathrm{C}$ for 30 seconds, annealing for 40 seconds at $55^{\circ} \mathrm{C}$ and extension at $72^{\circ} \mathrm{C}$ for 40 seconds completion with $72{ }^{\circ} \mathrm{C}$ extension for 7 minutes. The thermocycling was conducted in XP Thermal Cycler apparatus (BIOER technology Co, Tokyo, Japan).

After the PCR, amplicons were digested by endonuclease LweI (Fermentas, Burlington, USA) at $37^{\circ} \mathrm{C}$ during 1 hour, according to the manufacturer's instructions. The fragments generated were separated by $2 \%$ agarose gel electrophore- sis containing ethidium bromide, followed by exposure to ultraviolet light. The figure 1 illustrates the electrophoretic patterns corresponding to each genotype.

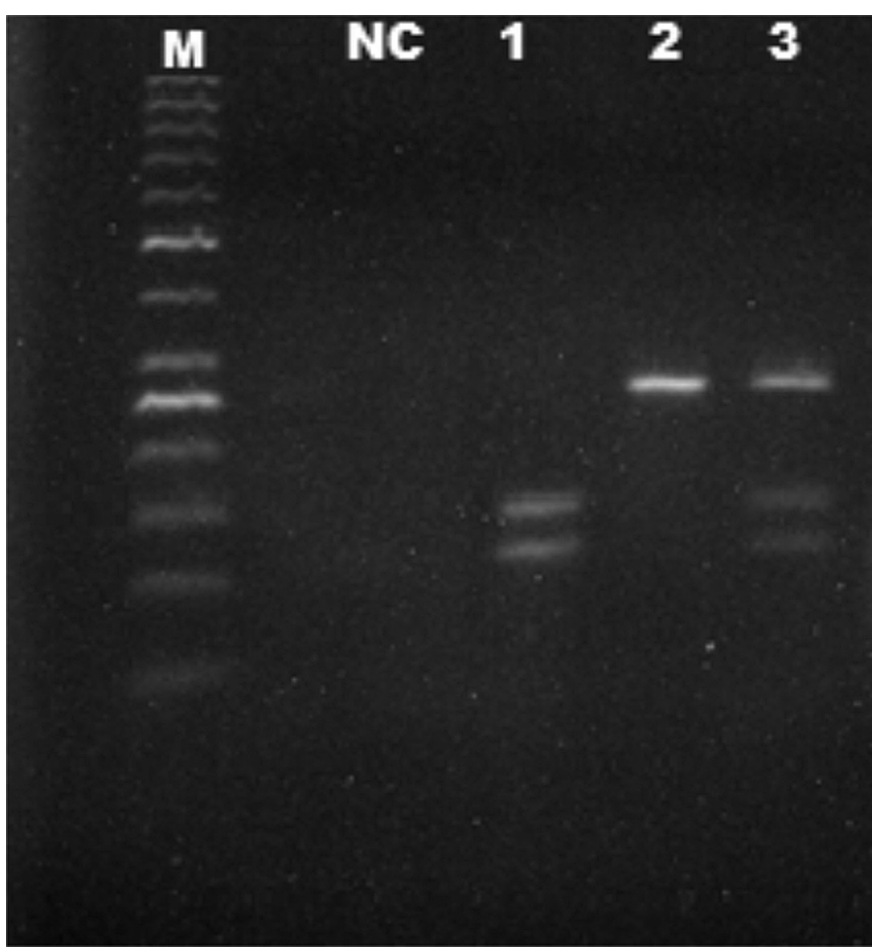

FIGURE 1. Electrophoretic profiles corresponding to homozigous genotypes GG (1) and AA (2) and heterozygous genotype AG (3) of the SNP T300A of the gene ATG16L1. M: molecular size standard (100 bp ladder, Fermentas, Ontario, Canada), NC: negative control.

\section{Statistical Analysis}

Proportions were employed for the categorical variables, while averages and standard deviations were used for the continuous ones. The possible genotypic and allelic association with the susceptibility to $C D$ was verified using the HDS software, based on $2 \times 2$ contingency tables, through Odds Ratio as indicator, adopting a confidence interval of $95 \%$ and considering significant the $P$ values lesser than 0.05 .

\section{Ethics Statements}

The patients were only included after elucidation of the aims of this work and their confirming of authorization via signature in Free and Informed Consent Form. The research was approved by the Institutional Review Board of the University of the Region of Joinville (Case No. 042/11), according to Brazilian ethical standards in research involving humans.

\section{RESULTS}

The group of patients was composed of 106 individuals, being 56 females and 50 males, with an average age of 41.4 
$( \pm 12.7)$ years old. The clinical characteristics are shown in Table 1. In the analysis of the distribution of genotype frequencies related to the SNP T300A we observed a higher frequency of the heterozygous genotype (50\%) compared to the homozygous genotypes AA $(26.4 \%)$ and GG $(23.6 \%)$. Concerning the allele frequencies, there was a slight predominance of the allele A (51.4\%) (Table 2).

TABLE 1. Clinical characteristics of the patients with Crohn's disease

\begin{tabular}{lc}
\hline Clinical Characteristics & Total $\mathbf{n}(\%)$ \\
\hline Gender & $56(52.8)$ \\
Female & $50(47.2)$ \\
Male & $41.4( \pm 12,7$ SD) \\
Age & $12(11,3)$ \\
Positive family history & \\
Disease location & $30(28.3)$ \\
Ileum only & $24(22.6)$ \\
Colon only & $49(46.2)$ \\
Ileum and colon & $26(24.5)$ \\
Perianal affect & $2(1.9)$ \\
Others (oral/oftamologic) & $43(40.5)$ \\
Clinical Behaviour & $33(31.1)$ \\
Non-stricturing/Non-fistulizing & \\
Stricturing & $39(36.8)$ \\
Fistulizing & \\
Need for surgery & \\
\hline & \\
\hline
\end{tabular}

The control group totalized 238 volunteers with an average age of $32( \pm 10.6)$ years old and was composed mainly by males $(67.7 \%)$. According to the results of genotyping, a higher frequency of the heterozygous genotype (44.8\%) was observed when compared to homozygote genotypes AA $(35.1 \%)$ and GG $(20.1 \%)$. Regarding the allele frequencies, there was also a predominance of the allele A among controls $(57.3 \%)$, without significant differences between groups.

\section{DISCUSSION}

The major technological breakthrough occurred over the past few years, especially in the last decade, has enabled the development of analytical techniques of molecular biology of tissues and also brought a renewal of hope on the possibility of answers in the field of IBD $^{(13)}$.

Although groups of family members have been described in $\mathrm{CD}$, genes considered as susceptibility factors were not pointed until 2001, when NOD2/CARD1 $5^{(11)}$ was identified. The genetics of IBD, and especially of the CD, achieved a major breakthrough with the publication of the results of the first GWAS directed to such diseases ${ }^{(6)}$. From this pioneer study, several new susceptibility loci were identified, among these the gene ATG16L1, which was described by Hampe et al. ${ }^{(9)}$. Several polymorphisms and somatic alterations have been identified in the gene ATG16L1, highlighting the SNP T300A (rs2241880), whose allele $G$ appears to confer a higher risk for the development of $\operatorname{IBD}^{(3,5,8,17,19)}$.

Zhang et al. ${ }^{(19)}$ conducted an extensive meta-analysis aiming at understanding the role of the polymorphism T300A of the gene ATG16L1 as a susceptibility factor for CD involving 24 studies, totaling 13,022 cases and 17,532 controls. The authors found a positive association in Caucasians, but the same result was not possible to confirm in Asians, suggesting that this difference is possibly related to ethnic variations. This hypothesis was reinforced by the observation that the frequency of the allele $\mathrm{G}$ showed differences between these populations. Furthermore, none relevant clinical differences were found in association with the location of patients.

TABLE 2. Genotypic and allelic frequencies and associative analysis

\begin{tabular}{|c|c|c|c|c|c|}
\hline & Controls $(n=238)$ & $\mathrm{CD}(\mathrm{n}=106)$ & Comparison & OR (CI 95\%) & $P$ \\
\hline \multicolumn{6}{|c|}{ Genotype } \\
\hline AA & $84(35.3 \%)$ & $28(26.4 \%)$ & & & \\
\hline AG & $106(44.5 \%)$ & $53(50.0 \%)$ & $\mathrm{GG}+\mathrm{AG}$ vs $\mathrm{AA}$ & $1.519(0.889-2.606)$ & 0.134 \\
\hline GG & $48(20.2 \%)$ & $25(23.6 \%)$ & GG vs $A G+A A$ & $1.222(0.68-2.188)$ & 0.566 \\
\hline \multicolumn{6}{|c|}{ Allele } \\
\hline A & $274(57.6 \%)$ & $109(51.4 \%)$ & & & \\
\hline G & $202(42.4 \%)$ & $103(48.6 . \%)$ & G vs $A$ & $1.282(0.914-1.797)$ & 0.157 \\
\hline
\end{tabular}

OR: odds ratio 
TABLE 3. Genotypic distribution of the polymorphism T300A observed in diferent populations with Crohn's disease and controls

\begin{tabular}{lcccc|cccc}
\hline & \multicolumn{4}{c}{ Crohn's disease } & & \multicolumn{3}{c}{ Controls } \\
& n & \multicolumn{2}{c}{ Genotypes (\%) } & n & Genotypes (\%) \\
& & AA & AG & GG & & AA & AG & GG \\
\hline Present Study (2013); Brazil & 106 & $28(26.4 \%)$ & $53(50 \%)$ & $25(23.6 \%)$ & 238 & $84(35.1 \%)$ & $106(44.8 \%)$ & $49(20.1 \%)$ \\
Baptista et al. (2008); Brazil & 180 & $40(22.2 \%)$ & $94(52.2 \%)$ & $46(25, \%)$ & 189 & $57(30.1 \%)$ & $90(47.6 \%)$ & $42(22.2 \%)$ \\
Csöngei et al. ${ }^{(5)}$;Hungary & 315 & $56(16.2 \%)$ & $151(47.9 \%)$ & $108(34.2 \%)$ & 314 & $72(22.9 \%)$ & $163(46.2 \%)$ & $17(5.4 \%)$ \\
Márquez et al. ${ }^{(12)}$; Spain & 344 & $63(18.3 \%)$ & $156(45.3 \%)$ & $125(36.3 \%)$ & 745 & $177(23.7 \%)$ & $347(46.5 \%)$ & $221(29.6 \%)$ \\
Fowler et al. ${ }^{(7)}$; Australia & 823 & $133(16.1 \%)$ & $388(47.1 \%)$ & $302(36.6 \%)$ & 1664 & $425(25.5 \%)$ & $790(47.4 \%)$ & $449(26.9 \%)$ \\
\hline
\end{tabular}

In 2010, Cheng et al. ${ }^{(3)}$ published another meta-analysis including Asian, American, European and Oceanian populations. In this meta-analysis, the authors confirmed the positive association between the SNP T300A and susceptibility to CD. Two other studies, also published in 2010, corroborated this result ${ }^{(5,8)}$

The data on the variants distribution of the SNP T300A of the gene ATG16L1 in the Brazilian population are scarce. The only study known, published in 2008, based on the analysis of 180 patients with $\mathrm{CD}$, shows the following genotypic frequencies: $\mathrm{AA}-22.2 \%, \mathrm{AG}-54.2 \%$ and $\mathrm{GG}-25.5 \%{ }^{(1)}$. These data are compatible with the results obtained in this study, which cannot confirm a significant association between the polymorphism T300A and CD. No statistical differences were found when comparing cases and controls.

In comparison with other published studies (Table 3), we observed compatibility regarding the most frequent genotype: $\mathrm{AG}^{(1,5,7,12)}$. However, there is divergence among the higher frequency of homozygous genotypes in different populations, as mentioned by Zhang et al. ${ }^{(19)}$.

Our isolates results did not follow the global trend that shows increased susceptibility to CD in carriers of the genotype GG of rs2241880 in various populations ${ }^{(3,5,7,8,12,19)}$. However, we decided to speculate what would be observed when adding the number of samples from Baptista et al. ${ }^{(1)}$, also belonging to Southern individuals, with the numbers of the current study, which amounted 286 Brazilian patients with $\mathrm{CD}$. Of the whole patients, $23.7 \%$ show homozygous genotype AA, $51.3 \%$ heterozygous AG and $24.8 \%$ homozygous GG. By applying the same statistical tools in this larger group in comparison with controls, the polymorphism T300A was significantly associated $(P=0.01, \mathrm{OR}=0.633$ [0444-0900]) with CD (Table 4). This finding confirms that the size of our sample, when compared to other population studies, have directly influenced our results.

We emphasize that further investigations related to the SNP T300A of the gene ATG16L1 and to other genes possibly associated with susceptibility to CD must be conducted in the Brazilian population and thus contribute with additional data for the purpose of elucidating the natural history and pathophysiology of this disease.

\section{ACKNOWLEDGEMENTS}

The authors thank the medical colleagues for their contribution to this work, especially Harry Kleinubing Júnior, Paulo Gustavo kotze, Éverson Fernando Mallutta, Juliano Coelho Ludvig, Antônio Baldin Júnior, and Maria Gabriela Lazcano Alves Ferreira, who have contributed with data and samples.

TABLE 4. Genotypic and allelic frequencies and associative analysis considering the sample of Batista et al. (2008) added to the one of the current study

\begin{tabular}{|c|c|c|c|c|c|}
\hline & Controls $(\mathrm{n}=427)$ & $\mathrm{CD}(\mathrm{n}=286)$ & Comparison & OR (CI 95\%) & $P$ \\
\hline \multicolumn{6}{|c|}{ Genotype } \\
\hline AA & 141 & 68 & & & \\
\hline AG & 196 & 147 & $\mathrm{AA}$ vs $\mathrm{AG}+\mathrm{GG}$ & $0.633(0.444-0.900)$ & 0.010 \\
\hline GG & 90 & 71 & GG vs $A G+A A$ & $0.809(0.558-1.172)$ & 0.280 \\
\hline \multicolumn{6}{|l|}{ Allele } \\
\hline A & $478(55.97 \%)$ & $283(49.48 \%)$ & & & \\
\hline G & $376(44.03 \%)$ & $289(50.52 \%)$ & G vs $A$ & $1.298(1.044-1.615)$ & 0.019 \\
\hline
\end{tabular}


Scolaro BL, Santos E, Ferreira LE, França PHC, Kleinubing H, Kotze PG, Pinho MSL. Polimorfismo genético T300A: fator de susceptibilidade para doença de Crohn? Arq Gastroenterol. 2014,51(2):97-101.

RESUMO - Contexto - A doença de Crohn caracteriza-se por uma desordem inflamatória, crônica e debilitante do trato gastrointestinal. Diversos fatores contribuem para seu desenvolvimento. A partir da realização de estudos amplos do genoma, o polimorfismo T300A do gene ATG16L1 (autophagyrelated 16-like 1) tem sido relacionado com aumento de susceptibilidade ao desenvolvimento desta doença. Objetivos - Analisar a incidência do polimorfismo T300A (rs2241880) em pacientes com doença de Crohn. Métodos - Foram analisadas 238 amostras de doadores de sangue (grupo controle) e 106 amostras de pacientes com doença de Crohn, procedentes de cinco centros. A genotipagem consistiu em amplificação do segmento gênico T300A, via reação em cadeia da polimerase, seguidos da análise de polimorfismo de comprimentos dos fragmentos de restrição. Os amplicons e fragmentos foram separados via eletroforese em gel de agarose e visualizados sob luz ultravioleta. Resultados - O genótipo AG foi mais prevalente entre os pacientes e controles ( $50 \%$ vs $44,8 \%$ ), seguido dos genótipos AA (26,4\% vs $35,1 \%)$ e GG $(23,6 \%$ vs $20,1 \%)$. A freqüência do alelo G do polimorfismo T300A foi maior no grupo de pacientes com doença de Crohn (48,6\%) do que nos controles (42,4\%), embora sem significância estatística. Conclusões - Não foi possível confirmar o aumento de susceptibilidade à doença de Crohn conferido pelo polimorfismo T300A.

DESCRITORES - Doença de Crohn. Proteínas de transporte, genética. Polimorfismo de nucleotídeo único.

\section{REFERENCES}

1. Baptista ML, Amarante H, Picheth G, Sdepanian VL, Peterson N, Babasukumar U. CARD15 and IL23R influences Crohn's disease susceptibility but not disease phenotype in a Brazilian population. Inflamm Bowel Dis. 2008;14:674-9.

2. Brasil. Portal da Saúde. Doença de Crohn. [cited 01 Mai 2013]. Available from:<http://portal.saude.gov.br/saude/visualizar_texto.cfm?idtxt=23529>.

3. Cheng JF. T300A polymorphism of ATG16L1 and susceptibility to inflammatory bowel diseases: A meta-analysis. WJG. 2010;16:1258.

4. Crohn BB, Ginzburg L, Oppenheimer GD. Regional Ileitis: A Pathologic and Clinical Entity. JAMA. 1932;99:1323-9.

5. Csöngei V. Interaction of the major inflammatory bowel disease susceptibility alleles in Crohn's disease patients. WJG. 2010;16:176.

6. Duerr RH. Genome-wide association studies herald a new era of rapid discoveries in inflammatory bowel disease research. Gastroenterology. 2007;132:2045-9.

7. Fowler EV, Doecke J, Simms LA, Zhao ZZ, Webb PM, Hayward NK, Whiteman C, Florin TH, Montgomery GW, Cavanaugh JA, Radford-Smith GH. ATG16L1 T300A shows strong associations with disease subgroups in a large Australian IBD population: further support for significant disease heterogeneity. AJG. 2008;103:2519-26.

8. Gazouli M. NOD2 / CARD15, ATG16L1 and IL23R gene polymorphisms and childhood-onset of Crohn's disease. WJG. 2010;16:1753.

9. Hampe J, Franke A, Rosenstiel P, Till A, Teuber M, Huse K, et al. A genome-wide association scan of nonsynonymous SNPs identifies a susceptibility variant for Crohn disease in ATG16L1. Nat Genet. 2007;39:207-11.

10. Koltum WA. Inflammatory Bowel Disease: Diagnosis and Evaluation. The ASCRS Textbook of Colon and Rectal Surgery. 2007:544.
11. Kucharzik T, Maaser C, Lügering A, Kagnoff M, Mayer L, Targan S. Recent understanding of IBD pathogenesis: implications for future therapies. Inflamm Bowel Dis. 2006;12:1068-83.

12. Marquez A, Nunes C, Martinez A, Mendonza JL, Taxonera C, Fernandez-Arquero M,et al. Role of ATG16L1 Thr300Ala Polymorphism in Inflammatory Bowe Disease: A Study in the Spanish Population and a Mata-analysis. Inflamm Bowe Dis. 2009;15:1697-704.

13. Pinho MA. Biologia molecular das doenças inflamatórias intestinais. Journal of Coloproctology. 2008;28(1).

14. Plantinga TS, Crisan TO, Oosting M, van de Veerdonk FL, de Jong DJ, Philpott DJ. Crohn's disease-associated ATG16L1 polymorphism modulates pro-inflammatory cytokine responses selectively upon activation of NOD2. Gut. 2011;60:122935.

15. Scaldaferri F, Fiocchi C. Inflammatory bowel disease: progress and current concepts of etiopathogenesis. J Dig Dis. 2007;8(4):171-8.

16. Schirbel A, Fiocchi C. Inflammatory bowel disease: Established and evolving considerations on its etiopathogenesis and therapy. J dig dis. 2010:11:266-76.

17. Schmid D, Dengjel J, Schoor O, Stevanovic S, Münz C. Autophagy in innate and adaptive immunity against intracellular pathogens. Journal of molecular medicine (Berlin, Germany). 2006;84:194-202.

18. Tsianos EV, Katsanos KH, Tsianos VE. Role of genetics in the diagnosis and prognosis of Crohn's disease. WJG. 2012;18:105-18.

19. Zhang H-F, Qiu L-X, Chen Y, Zhu W-L, Mao C, Zhu L-G, et al. ATG16L1 T300A polymorphism and Crohn's disease susceptibility: evidence from 13,022 cases and 17,532 controls. Hum Genet. 2009;125:627-31.

Received 27/10/2013 Accepted 5/12/2013 